\title{
GMR
}

\section{Propofol induces apoptosis and inhibits the proliferation of rat embryonic neural stem cells via gamma-aminobutyric acid type A receptor}

\author{
J.W. Wang ${ }^{1}$, W.W. Cheng ${ }^{2}$, T. Xu1 and Z.Y. Yang ${ }^{1}$ \\ 1'Department of Anesthesiology, International Peace Maternity and Child Health Hospital, \\ Shanghai Jiaotong University, Shanghai, China \\ 2Department of Obstetrics, International Peace Maternity and Child Health Hospital, \\ Shanghai Jiaotong University, Shanghai, China \\ Corresponding author: W.W. Cheng \\ E-mail: cheww111@126.com
}

Genet. Mol. Res. 14 (4): 14920-14928 (2015)

Received June 16, 2015

Accepted September 13, 2015

Published November 18, 2015

DOI http://dx.doi.org/10.4238/2015.November.18.57

ABSTRACT. We investigated the effect of propofol on the proliferation and viability of rat embryonic neural stem cells (rENSCs) and the potential mechanisms involved. rENSCs were isolated and cultured in vitro and treated with 1,10 , or $50 \mu \mathrm{M}$ propofol, while the control group was treated with 0.1 $\mu \mathrm{M}$ dimethyl sulfoxide. The effect of propofol on the proliferation and viability of rENSCs was examined by proliferation and apoptosis assays. Real-time polymerase chain reaction was employed to analyze the mRNA expression of checkpoint kinase 1 (Chk1) and p53 in rENSCs exposed to propofol. Immunoprecipitation assay and western blotting analysis were performed to analyze the effect of propofol on Chk1 and p53 activity. The gammaaminobutyric acid type $A\left(G_{B B A}\right)$ receptor antagonist securinine was added to the rENSCs before being treated with propofol to investigate the role of the $\mathrm{GABA}_{\mathrm{A}}$ receptor in propofol-triggered effects on rENSCs. rENSCs specifically expressing nestin protein were successfully isolated and cultured for experiments. The inhibitory effect of propofol on rENSCs increased dose- 
dependently. The percentage of apoptotic cells increased to $11.7 \%$ and the activity of Chk1 and p53 enhanced after treatment with $50 \mu \mathrm{M}$ propofol. However, addition of securinine abrogated propofol-induced apoptosis and

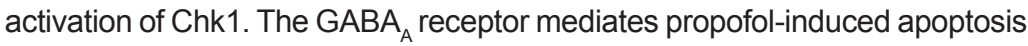
and proliferation inhibition of rENSCs, possibly by modulating the Chk1/p53 signaling pathway.

Key words: Apoptosis; Gamma-aminobutyric acid type A receptor; p53; Checkpoint kinase 1; Cell proliferation; Propofol

\section{INTRODUCTION}

Propofol, also known as diprivan, is an intravenously administered hypnotic agent with an attractive pharmacokinetic profile of rapid onset and a short recovery period from general anesthesia (Miner and Burton, 2007; Rasmussen, 2014). Propofol is widely used for the induction and maintenance of general anesthesia and for procedural sedation (Miner and Burton, 2007; Rasmussen, 2014). The gamma-aminobutyric acid type $A\left(G A B A_{A}\right)$ receptor is a chloride-selective ligand-gated ion channel that causes an inhibitory effect on neurotransmission upon activation (Zhao et al., 2014). It is thought that propofol exerts its anesthetic action by potentiating $\mathrm{GABA}_{\mathrm{A}}$ receptor activity, and studies have shown that propofol can directly bind to the $\mathrm{GABA}_{\mathrm{A}}$ receptor. While the binding domain of the $\mathrm{GABA}_{\mathrm{A}}$ receptor has been previously identified (Bali and Akabas, 2004; Willis et al., 2014), the molecular mechanisms of the anesthetic effect of propofol and the downstream signaling pathway of the $\mathrm{GABA}_{\mathrm{A}}$ receptor remain unclear.

Propofol has also been frequently used in pediatric anesthetic practice to facilitate surgical procedures, sedation, imaging studies, and intensive care (Istaphanous and Loepke, 2009). However, increasing evidence from animal studies suggests that high doses of propofol or prolonged exposure to propofol may induce neuronal cell apoptosis in the developing brain, raising serious questions regarding the safety of propofol for pediatric anesthesia (Fredriksson et al., 2007; Cattano et al., 2008; Bercker et al., 2009; Istaphanous and Loepke, 2009; Zou et al., 2013). Fredriksson et al. (2007) reported that injection of propofol at a high dose of $60 \mathrm{mg} / \mathrm{kg}$ into day 10 Naval Medical Research Institute mice triggered neuronal cell apoptosis in the brain, with similar results observed by Cattano et al. (2008) Recently, a study by Zou et al. (2013) showed that the exposure of rat embryonic neural stem cells (rENSCs) to high doses of propofol led to cell apoptosis. However, the molecular mechanism underlying the induction of neuronal cell apoptosis by propofol remains unclear.

Checkpoint kinase 1 (Chk1) and p53 are important regulators of cell proliferation and apoptosis (Liu et al., 2000; Takai et al., 2000; Haupt et al., 2003; Lam et al., 2004; Shimada et al., 2008). In this study, we examined the activity of Chk1 and p53 in rENSCs upon induction with propofol and investigated the role of the $\mathrm{GABA}_{\mathrm{A}}$ receptor in propofol-induced neuroapoptosis to investigate the mechanism by which propofol induces neuronal cell apoptosis.

\section{MATERIAL AND METHODS}

\section{Isolation and culture of rENSCs}

Pregnant Sprague-Dawley rats were supplied by Shanghai Laboratory Animal Center 
(Shanghai, China). Rat embryos were obtained at 14 days of gestation and the cerebral cortex was removed and washed with D-Hank's solution. After removing the meninges and blood vessels, the cerebral cortex was minced and transferred to a 5-mL sterilized Eppendorf tube containing $0.25 \%$ trypsin and $0.02 \%$ EDTA. Digestion with trypsin/EDTA was performed at $37^{\circ} \mathrm{C}$ for 5 min followed by centrifugation at $336 \mathrm{~g}$ for $4 \mathrm{~min}$. The supernatant was removed and pelleted cells were resuspended in DMEM/F12 culture medium (Gibco, Grand Island, NY, USA) containing 10\% fetal bovine serum (Gibco), supplemented with 2\% B27 (Gibco), 1\% N2 (Gibco), 20 ng/mL epidermal growth factor (Gibco), and $20 \mathrm{ng} / \mathrm{mL}$ basic fibroblast growth factor (Gibco), as well as $100 \mathrm{U} / \mathrm{mL}$ penicillin and $100 \mu \mathrm{g} / \mathrm{mL}$ streptomycin. Cells were transferred to cell culture flasks and incubated at $37^{\circ} \mathrm{C}$ in humidified air containing $5 \% \mathrm{CO}_{2}$. The study was approved by the local Academic Research Ethics Committee.

\section{Cell proliferation and apoptosis assay}

The cell proliferation assay was performed using the Quick Cell Proliferation Assay Kit (Biovision, Inc., Milpitas, CA, USA) according to the manufacturer instructions. rENSCs were seeded on 96-well plates at a density of $7 \times 10^{4}$ cells per well with $100 \mu \mathrm{L}$ medium and incubated for $24 \mathrm{~h}$ at $37^{\circ} \mathrm{C}$ in humidified air containing $5 \% \mathrm{CO}_{2}$. Propofol dissolved in dimethyl sulfoxide (DMSO) (Sigma, St. Louis, MO, USA) was added at concentrations of 1, 10, and $50 \mu \mathrm{M}$, while some wells of cells were treated with $0.1 \% \mathrm{DMSO}$ as controls. To analyze the role of the $\mathrm{GABA}_{\mathrm{A}}$ receptor in the effect of propofol on cell growth, the $\mathrm{GABA}_{\mathrm{A}}$ receptor antagonist securinine was added at a final concentration of $0.1 \mu \mathrm{M}$. Each sample was tested in triplicate. After culture for $12,24,36$, and 48 $\mathrm{h}, 10 \mu \mathrm{L}$ WST-1 solution was added into each well and cells were incubated for another $3 \mathrm{~h}$. The optical density of each well was measured using an enzyme-linked immunosorbent assay reader at a wavelength of $440 \mathrm{~nm}$.

Apoptosis was detected using the MitoCapture Apoptosis Detection Kit (Biovision) according to the manufacturer instructions. Apoptotic cells were analyzed by flow cytometry with a fluorescein isothiocyanate channel $(E x / E m=488 / 530+30 \mathrm{~nm})$.

\section{Western blotting analysis}

Cells were collected and lysed with pre-cooled RIPA lysis buffer supplemented with $1 \mathrm{mM}$ phenylmethylsulfonyl fluoride and fresh protease inhibitor cocktail. The cell lysate was centrifuged at $13,000 \mathrm{rpm} / \mathrm{min}$ at $4^{\circ} \mathrm{C}$ for $20 \mathrm{~min}$ and the supernatant was collected. After determining the protein concentration using the BCA Protein Assay (Pierce, Rockford, IL, USA), equal amounts of protein were separated by sodium dodecyl sulfate-polyacrylamide gel electrophoresis and then electrotransferred to polyvinylidene fluoride membranes. After blocking with $5 \%(\mathrm{w} / \mathrm{v})$ non-fat milk in Tris-buffered saline at room temperature for $1 \mathrm{~h}$, the membranes were separately incubated with the following primary antibodies: anti-Nestin (Santa Cruz Biotechnology, Inc., Santa Cruz, CA, USA), anti-Chk1 (Santa Cruz), anti-p53 (Santa Cruz), anti-Chk1 pS317 (Cell Signaling Technology, Danvers, MA, USA), and anti- $\beta$-tubulin (Boster Biological Technology, Wuhan, China) for $2 \mathrm{~h}$ at room temperature. After extensive washing with $0.1 \%$ Triton $\mathrm{X}-100$ in Tris-buffered saline, the membranes were incubated with horseradish peroxidase-conjugated secondary antibodies (Boster Biological Technology) for $1 \mathrm{~h}$ at room temperature before analysis using electrochemiluminescence western blotting detection reagents. 


\section{Immunoprecipitation assay}

An immunoprecipitation assay was performed using Seize Primary Immunoprecipitation Kits (Thermo Fisher Scientific, Inc., Waltham, MA, USA) according to the manufacturer instructions. Briefly, the p-Ser/Thr/Tyr antibody was conjugated to the AminoLink ${ }^{\circledR}$ Plus Coupling Gel and cultured with cell lysate at $4^{\circ} \mathrm{C}$ for $4 \mathrm{~h}$ to immunoprecipitate the phosphorylated protein. After washing with phosphate-buffered saline thrice, gels were collected by centrifugation at $1000 \mathrm{rpm}$ at $4^{\circ} \mathrm{C}$ for 2 min and then protein was eluted with elution buffer before analysis by western blotting.

\section{Real-time polymerase chain reaction (PCR)}

Total RNA was extracted using Total RNA Purification Kits (Norgen Biotek Corp., Ontario, Canada) and cDNA was synthesized using reverse transcription reagents (TaKaRa, Shiga, Japan) according to the manufacturer instructions. Real-time PCR was performed using SsoAdvanced SYBR Green Supermix (Bio-Rad, Hercules, CA, USA) in a 10- $\mu$ L reaction system, which included the following: $0.5 \mu \mathrm{L}$ cDNA temperate (100 ng), $1 \mu \mathrm{L}$ forward and reverse primers, $5 \mu \mathrm{L}$ Super mix, and $3.5 \mu \mathrm{L}$ nuclease-free water. The PCR conditions were as follows: $94^{\circ} \mathrm{C}$ for $4 \mathrm{~min}, 32$ cycles each at $94^{\circ} \mathrm{C}$ for $40 \mathrm{~s}, 56^{\circ} \mathrm{C}$ for $20 \mathrm{~s}$, and $72^{\circ} \mathrm{C}$ for $90 \mathrm{~s}$, and then one cycle at $72^{\circ} \mathrm{C}$ for $10 \mathrm{~min}$. The primer sequences are shown in Table 1 and mRNA levels were determined as described previously (Livak and Schmittgen, 2001).

\begin{tabular}{|c|c|c|}
\hline Gene & Accession & Primer $\left(5^{\prime}-3^{\prime}\right)$ \\
\hline \multirow[t]{2}{*}{ p53 } & NM_001003210.1 & F: TCAACAAGATGTTTTGCCAACTG \\
\hline & & R: ATGTGCTGTGACTGCTTGTAGATG \\
\hline \multirow[t]{2}{*}{ Chk1 } & NM_007691.5 & F: GGTGAATATAGTGCTGCTATGTTGACA \\
\hline & & R: TTGGATAAACAGGGAAGTGAACAC \\
\hline \multirow[t]{2}{*}{$\beta$-actin } & NM_007393.3 & F: CACCCGCGAGTACAACCTTC \\
\hline & & R: CCCATACCCACCATCACACC \\
\hline
\end{tabular}

$\mathrm{F}=$ forward; $\mathrm{R}$ = reverse.

\section{Statistical analysis}

Data analyses were performed using the SPSS 11.5 software (SPSS, Inc., Chicago, IL, USA) and results are reported as means \pm SD. One-way analysis of variance was used to determine the differences among groups, while $t$-test was used for differences between 2 groups. $\mathrm{P}<0.05$ was considered to indicate significance.

\section{Ethics statement}

All animal experiments in this study were performed in accordance with the authors' Institutional Ethics Committee approval.

\section{RESULTS}

\section{Propofol induced apoptosis and inhibited proliferation of rENSCs}

rENSCs were isolated and cultured as described in Materials and Methods. Nestin, an 
intermediate filament protein, is regarded as a marker of neural stem/progenitor cells (Gilyarov, 2008). The expression of nestin in rENSCs and C6 rat glioma cell line was examined by western blotting. As shown in Figure 1A, nestin was specifically expressed in rENSCs but undetectable in C6 cells. These nestin-positive rENSCs were cultured and amplified for subsequent experiments.

To investigate the effect of propofol on rENSC proliferation, cells were treated with 1 , 10 , or $50 \mu \mathrm{M}$ propofol for $12,24,36$, and $48 \mathrm{~h}$ and cell activity was determined using a Quick Cell Proliferation Assay Kit. Prolonged exposure to propofol clearly inhibited the proliferation of rENSCs, and propofol at $50 \mu \mathrm{M}$ significantly reduced the proliferative rate of rENSCs compared with cells treated with $0.1 \%$ DMSO $(P<0.05$; Figure $1 \mathrm{~B})$.

For apoptosis analysis, rENSCs were treated with different doses of propofol for 48 $\mathrm{h}$, and cell apoptosis was analyzed by flow cytometry. With increasing propofol concentration, rENSC apoptosis increased in a dose-dependent manner. Cell apoptosis increased to $11.7 \%$ upon induction with $50 \mu \mathrm{M}$ propofol, which was significantly higher than that in cells treated with $0.1 \%$ DMSO ( $P<0.05$; Figure 1C).
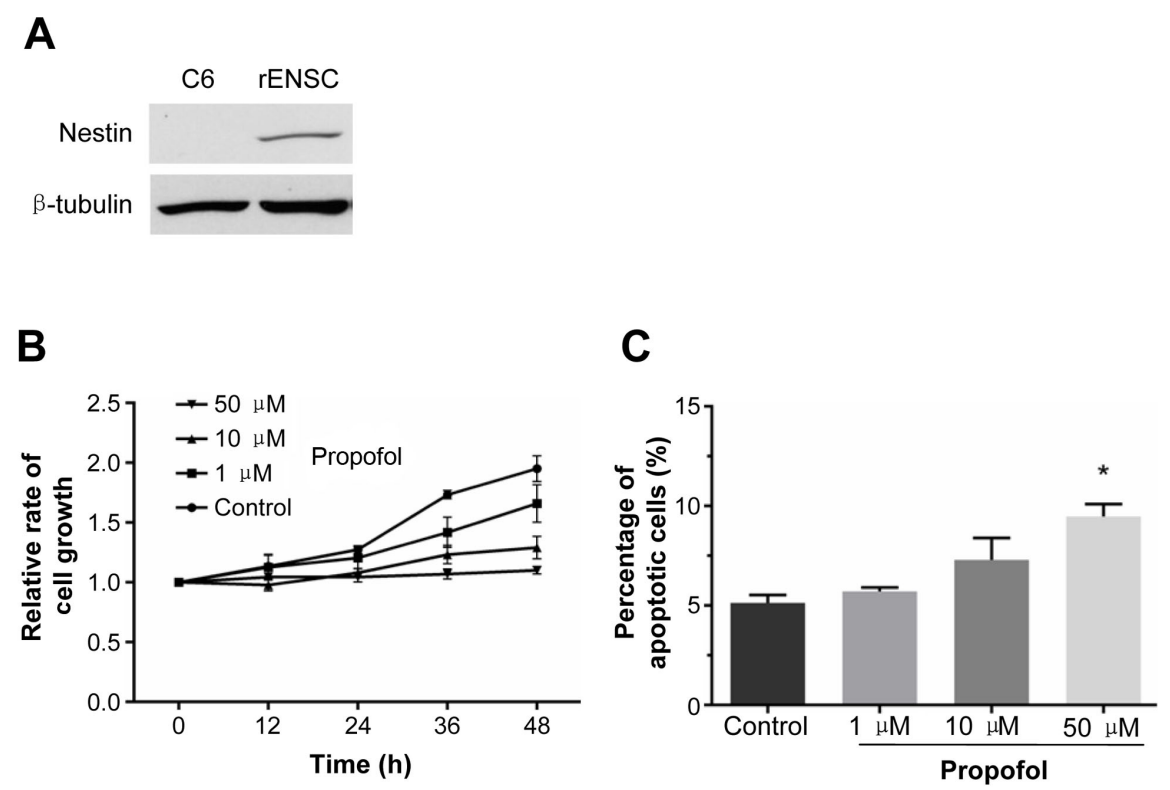

Figure 1. Propofol induced apoptosis and inhibited proliferation of rENSCs. A. Nestin was specifically expressed in rENSCs. The expression of nestin was detected in rENSCs and C6 rat glioma cell line by western blotting. $\beta$-tubulin was used as a control. B. Propofol inhibits the proliferation of rENSCs. The rENSCs were treated with 1, 10, or 50 $\mu \mathrm{M}$ propofol for $12,24,36$, and $48 \mathrm{~h}$, followed by a proliferation assay. C. Propofol stimulated rENSCs apoptosis. The rENSCs were treated with 1,10 , or $50 \mu \mathrm{M}$ of propofol for $48 \mathrm{~h}$, followed by an apoptotic assay. The percentage of apoptotic cells was analyzed by flow cytometry. ${ }^{*} \mathrm{P}<0.05$ compared with control group.

\section{Propofol affected the activity of Chk1 and p53}

Chk1 and p53 are well-known as vital regulators of cell proliferation and apoptosis (Liu et al., 2000; Takai et al., 2000; Haupt et al., 2003; Lam et al., 2004; Shimada et al., 2008). Because propofol induced apoptosis and inhibited the proliferation of rENSCs (Figure 1), we explore whether propofol affected the activity of Chk1 and p53 in rENSCs. First, the mRNA expression 
of Chk1 and p53 was examined in rENSCs exposed to different concentrations of propofol for $48 \mathrm{~h}$. No obvious differences in Chk1 mRNA levels were observed $(P>0.05)$, while the p53 level was enhanced slightly with increasing propofol concentration (Figure 2A). However, there was no significant statistically significant difference in p53 mRNA levels in rENSCs treated with or without propofol (P > 0.05; Figure 2A).

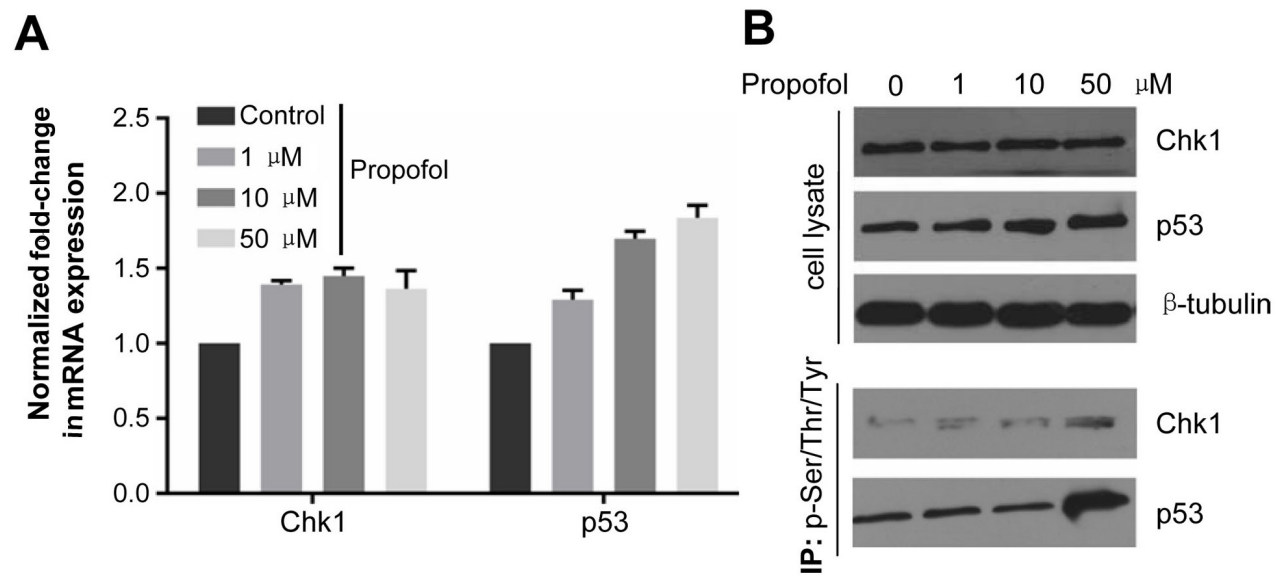

Figure 2. Propofol enhanced the phosphorylation of Chk1 and p53. A. Propofol did not affect the mRNA levels of Chk1 and p53. The rENSCs were treated with 1, 10, or $50 \mu \mathrm{M}$ propofol for $48 \mathrm{~h}$, and then the mRNA levels of Chk1 and p53 were analyzed by real-time PCR. B. Propofol increased phosphorylation of Chk1 and p53. The rENSCs were treated with 1, 10, or $50 \mu \mathrm{M}$ propofol for $48 \mathrm{~h}$, and then harvested for western blot analysis. The expression of Chk1 and p53 in the cell lysate was detected, and $\beta$-tubulin was used as a control. The phosphorylation protein was immunoprecipitated (IP) with p-Ser/ Thr/Tyr antibody-conjugated AminoLink ${ }^{\circledR}$ Plus Coupling Gel, and then detected using anti-Chk1 and anti-p53 antibodies.

In order to investigate the activity of Chk1 and p53 upon induction with propofol, the phosphorylation states of Chk1 and p53 were examined by western blotting. There were no clear differences in protein expression of Chk1 and p53 in rENSCs treated with or without propofol (Figure 2B), which is consistent with the results shown in Figure 2A. All phosphorylated protein in rENSCs upon induction with propofol was immunoprecipitated and the phosphorylation state of Chk1 and p53 was detected. As shown in Figure 2B, the phosphorylation levels of Chk1 and p53 clearly increased in rENSCs when induced with $50 \mu \mathrm{M}$ propofol (Figure 2B), indicating that propofol affected the activity of Chk1 and p53. These results suggest that Chk1 and p53 are involved in modulating the apoptosis and proliferation inhibition of rENSCs induced by propofol.

\section{$\mathrm{GABA}_{\mathrm{A}}$ receptor mediates the toxic effect of propofol on rENSCs}

The anesthetic action of propofol is thought to occur through the potentiation of $\mathrm{GABA}_{A}$ receptor activity (Bali and Akabas, 2004; Willis et al., 2014). We investigated whether the GABA $A_{A}$ receptor mediates the toxic effects of propofol on rENSCs. To examine this, $0.1 \mu \mathrm{M}$ securinine, GABA $_{A}$ receptor antagonist, was added to cells treated with or without propofol, and then apoptosis was evaluated. No significant difference in the percentage of cell apoptosis was observed between groups $(P>0.05$; Figure $3 A$ ), indicating that securinine abrogated the apoptotic effect on rENSCs triggered by the high $50 \mu \mathrm{M}$ dose of propofol (Figure 1C). Next, we explored whether securinine 
interfered with propofol-induced elevation of Chk1 phosphorylation. rENSCs exposed to different doses of propofol were also treated with $0.1 \mu \mathrm{M}$ securinine, and then lysed for western blotting detecting with a Chk1-pS317 antibody. The phosphorylation level of Chk1 on Ser317 clearly increased with increasing propofol concentration (Figure 3B, upper panel), but addition of securinine abrogated the variation induced by propofol. These results suggest that the $G_{A B A}$ receptor may mediate the toxic effect of propofol on rENSCs.

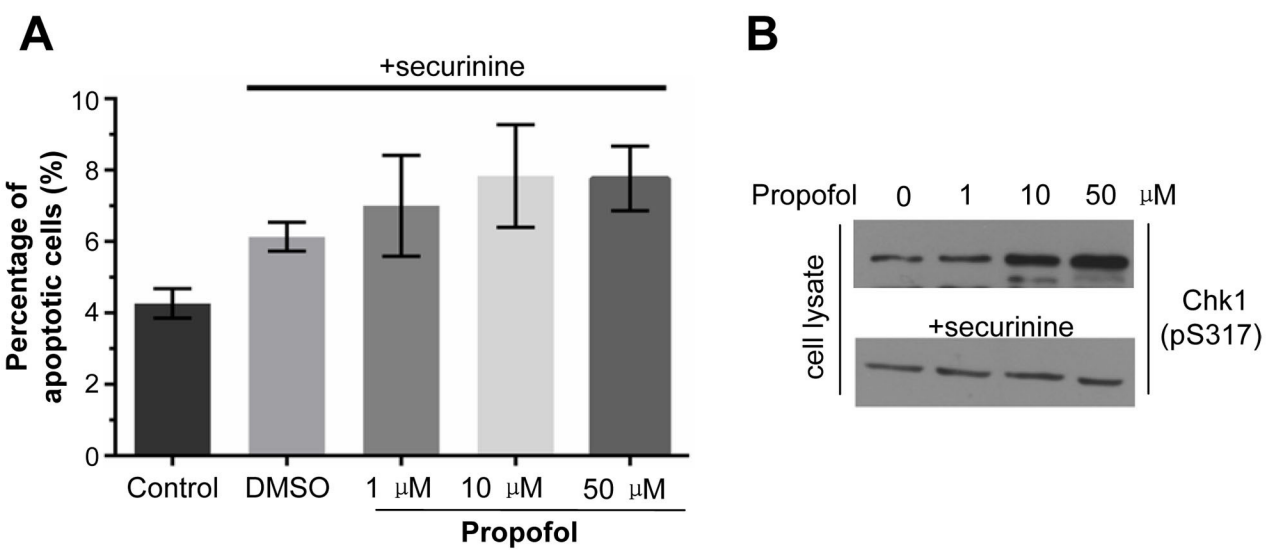

Figure 3. $G A B A_{A}$ receptor was involved in modulating the propofol-induced toxic effect on $r E N S C$ s. A. The GABA receptor antagonist securinine abrogated the apoptotic effect on rENSCs triggered by propofol. The rENSCs were treated with 1,10 , or $50 \mu \mathrm{M}$ propofol together with or without $0.1 \mu \mathrm{M}$ securinine for $48 \mathrm{~h}$, followed by a proliferation assay. B. Securinine abrogated the propofol-induced elevation of Chk1 phosphorylation on Ser317. The rENSCs were treated with 1,10 , or $50 \mu \mathrm{M}$ propofol with or without $0.1 \mu \mathrm{M}$ securinine for $48 \mathrm{~h}$, and cells were harvested for western blot analysis with anti-Chk1-pS317 antibody.

\section{DISCUSSION}

The mechanism of anesthetic action and safety evaluation of anesthetic drugs have been widely investigated. Because of advantages such as a controllable anesthetic state as well as rapid onset and offset, the hypnotic agent propofol is favored for use in anesthetic practice, including pediatric anesthesia (Miner and Burton, 2007; Istaphanous and Loepke, 2009; Rasmussen, 2014). However, animal studies have shown that large doses of propofol or prolonged exposure to propofol causes neuronal cell apoptosis in the developing brain (Fredriksson et al., 2007; Cattano et al., 2008; Bercker et al., 2009; Istaphanous and Loepke, 2009; Zou et al., 2013). However, the molecular mechanism by which propofol induces neuronal cell apoptosis is not well understood. In the present study, rENSCs were isolated, cultured in vitro, and treated with propofol to investigate propofol-induced rENSC apoptosis and its potential mechanism. It was previously shown that the concentration of propofol in the human brain ranged from 22-73 $\mu \mathrm{M}$ during clinical practice (Ludbrook et al., 2002). Thus, 1-50 $\mu \mathrm{M}$ propofol, relative to clinical application, was used in this study. Our results revealed that propofol inhibited the proliferation of rENSCs in a dose-dependent manner and that $50 \mu \mathrm{M}$ propofol caused significant cell apoptosis $(P<0.05$; Figure 1).

Chk1 is a Ser/Thr-protein kinase that coordinates the DNA damage response and cell 
cycle checkpoint response. Activation of Chk1 results in cell cycle arrest to prevent damaged cells from progressing through the cell cycle (Liu et al., 2000; Takai et al., 2000; Lam et al., 2004; Shimada et al., 2008). Chk1 can phosphorylate p53, enhancing its stability and activity and further promoting cell cycle arrest and inhibiting cell proliferation (Haupt et al., 2003; Chen and Poon, 2008). In the present study, the expression and activity of Chk1 and p53 in rENSCs exposed to propofol were investigated. The results of real-time PCR and western blot analysis showed that propofol did not affect the expression of Chk1 and p53 (Figure 2A). However, propofol induction greatly enhanced the phosphorylation of both Chk1 and p53. Because there are several phosphorylation sites on Chk1 and p53 (Figure 2B), we examined the overall phosphorylation state of Chk1 and p53 by immunoprecipitating the phosphorylated protein using a p-Ser/Thr/Tyr antibody-conjugated gel. In addition, the phosphorylation of Chk1 on Ser317 was notably elevated in propofol-induced cells, indicating that propofol induced activation of Chk1 kinase. Thus, our results suggest that propofol-induced proliferation inhibition is mediated by the Chk1 and p53 signaling pathway.

GABA, the endogenous ligand for the $\mathrm{GABA}_{A}$ receptor, is the major inhibitory neurotransmitter in central nervous system (Watanabe et al., 2014). It has been reported that propofol can directly bind to the $\mathrm{GABA}_{\mathrm{A}}$ receptor to potentiate the inhibitory effect on neurotransmission (Bali and Akabas, 2004; Willis et al., 2014). Thus, we investigated whether the GABA $A_{A}$ receptor mediates the propofol-induced inhibitory effect on cell proliferation. Several studies have shown that activation of the $\mathrm{GABA}_{\mathrm{A}}$ receptor significantly decreased the proliferation of neuronal cells (Antonopoulos et al., 1997; Andäng et al., 2008; Goffin et al., 2008). However, the molecular mechanisms and the downstream signaling pathway of the $\mathrm{GABA}_{A}$ receptor remain largely unknown. In the present study, treatment with the $\mathrm{GABA}_{A}$ receptor antagonist securinine abrogated propofol-induced apoptosis (Figure $3 \mathrm{~A}$ ), indicating that the $\mathrm{GABA}_{\mathrm{A}}$ receptor mediates the apoptotic effect of propofol on rENSCs. Moreover, securinine also diminished propofol-induced activation of Chk1 (Figure 3B). Thus, propofol induces apoptosis and proliferation inhibition of rENSCs, possibly through the $\mathrm{GABA}_{\mathrm{A}}$ receptor-Chk1/p53 signaling pathway. The protein interaction system and signaling pathway of Chk1 were analyzed using the STRING9.05 tool and KEGG PATHWAY Database (Figure S1). Our further studies will be aimed at determining the mechanisms underlying the propofol-induced inhibitory effect on neuronal cell proliferation.

In summary, we investigated the potential mechanism of propofol-induced toxic effects on neuronal stem cells, providing a theoretical and experimental basis for further studies on clinical practice with propofol, particularly in pediatric anesthesia.

\section{Conflicts of interest}

The authors declare no conflict of interest.

\section{Supplementary material}

\section{REFERENCES}

Andäng M, Hjerling-Leffler J, Moliner A, Lundgren TK, et al. (2008). Histone H2AX-dependent GABA(A) receptor regulation of stem cell proliferation. Nature 451: 460-464.

Antonopoulos J, Pappas IS and Parnavelas JG (1997). Activation of the GABAA receptor inhibits the proliferative effects of bFGF in cortical progenitor cells. Eur. J. Neurosci. 9: 291-298. 
Bali M and Akabas MH (2004). Defining the propofol binding site location on the GABAA receptor. Mol. Pharmacol. 65: 68-76. Bercker S, Bert B, Bittigau P, Felderhoff-Müser U, et al. (2009). Neurodegeneration in newborn rats following propofol and sevoflurane anesthesia. Neurotox. Res. 16: 140-147.

Cattano D, Young C, Straiko MM and Olney JW (2008). Subanesthetic doses of propofol induce neuroapoptosis in the infant mouse brain. Anesth. Analg. 106: 1712-1714.

Chen Y and Poon RY (2008). The multiple checkpoint functions of CHK1 and CHK2 in maintenance of genome stability. Front. Biosci. 13: 5016-5029.

Fredriksson A, Pontén E, Gordh T and Eriksson P (2007). Neonatal exposure to a combination of N-methyl-D-aspartate and gamma-aminobutyric acid type $\mathrm{A}$ receptor anesthetic agents potentiates apoptotic neurodegeneration and persistent behavioral deficits. Anesthesiology 107: 427-436.

Gilyarov AV (2008). Nestin in central nervous system cells. Neurosci. Behav. Physiol. 38: 165-169.

Goffin D, Aarum J, Schroeder JE, Jovanovic JN, et al. (2008). D1-like dopamine receptors regulate GABAA receptor function to modulate hippocampal neural progenitor cell proliferation. J. Neurochem. 107: 964-975.

Haupt S, Berger M, Goldberg Z and Haupt Y (2003). Apoptosis - the p53 network. J. Cell Sci. 116: 4077-4085.

Istaphanous GK and Loepke AW (2009). General anesthetics and the developing brain. Curr. Opin. Anaesthesiol. 22: 368-373.

Lam MH, Liu Q, Elledge SJ and Rosen JM (2004). Chk1 is haploinsufficient for multiple functions critical to tumor suppression. Cancer Cell 6: 45-59.

Liu Q, Guntuku S, Cui XS, Matsuoka S, et al. (2000). Chk1 is an essential kinase that is regulated by Atr and required for the G(2)/M DNA damage checkpoint. Genes Dev. 14: 1448-1459.

Livak KJ and Schmittgen TD (2001). Analysis of relative gene expression data using real-time quantitative PCR and the $2^{\Delta \triangle C}$ method. Methods 25: 402-408.

Ludbrook GL, Visco E and Lam AM (2002). Propofol: relation between brain concentrations, electroencephalogram, middle cerebral artery blood flow velocity, and cerebral oxygen extraction during induction of anesthesia. Anesthesiology 97: 1363-1370.

Miner JR and Burton JH (2007). Clinical practice advisory: Emergency department procedural sedation with propofol. Ann. Emerg. Med. 50: 182-187.e1.

Rasmussen KG (2014). Propofol for ECT anesthesia a review of the literature. J. ECT 30: 210-215.

Shimada M, Niida H, Zineldeen DH, Tagami H, et al. (2008). Chk1 is a histone H3 threonine 11 kinase that regulates DNA damage-induced transcriptional repression. Cell 132: 221-232.

Takai H, Tominaga K, Motoyama N, Minamishima YA, et al. (2000). Aberrant cell cycle checkpoint function and early embryonic death in Chk1(-/-) mice. Genes Dev. 14: 1439-1447.

Watanabe M, Fukuda A and Nabekura J (2014). The role of GABA in the regulation of GnRH neurons. Front. Neurosci. 8: 387.

Willis J, Zhu W, Perez-Downes J, Tan S, et al. (2014). Propofol-induced electroencephalographic seizures in neonatal rats: the role of corticosteroids and gamma-aminobutyric acid type A receptor-mediated excitation. Anesth. Analg. 120: 433-439.

Zhao C, Hwang SH, Buchholz BA, Carpenter TS, et al. (2014). GABAA receptor target of tetramethylenedisulfotetramine. Proc. Natl. Acad. Sci. U. S. A. 111: 8607-8612.

Zou WW, Xiao HP, Gu MN, Liu KX, et al. (2013). Propofol induces rat embryonic neural stem cell apoptosis by activating both extrinsic and intrinsic pathways. Mol. Med. Rep. 7: 1123-1128. 